\title{
What have we been thinking of? A critical overview of 40 years of student learning research in higher education
}

Tamsin Haggis*

Stirling Institute of Education, University of Stirling, Stirling FK9 4LA, UK

This article is a response to a request to consider the following three questions in relation to the recent history of research into student learning in higher education: What do we know?, What do we need to know?, and What might we do about it? A survey of article titles reporting on research into student learning was carried out in three key higher education journals, and the results of this were then considered in the context of other, related research perspectives. The article will first report on the results of this review, and then discuss these results in the context of theoretical moves in psychology and sociology over the same period of time. The trends identified in the higher education journals will then be compared to research into student learning in higher education which is published in two other disciplinary areas: adult education and sociolinguistics. After raising some questions that arise from these comparisons, the final section of the article will outline some suggestions about ways in which higher education researchers might begin to 'think differently' about learning and research in this field.

Universities today are homes of research into almost every subject save one themselves. There are few fields of social science in which painstaking investigation is more necessary and less often pursued. (Lord James of Rusholme [1965], quoted in Maton, 2004)

In the context of higher education, 'student learning research' is frequently taken to refer to the approaches to learning research, originated by Marton and Säljö (1984/ 1997 ) in the 1970s, and developed around the idea of 'deep' and 'surface' approaches to learning. Although an increasingly varied range of models and theoretical approaches to understanding student learning are becoming more prevalent in the literature, discussion about research into student learning in higher education is still frequently either based on these ideas, or takes them for granted (e.g. Gorsky, Caspi, and Trumper 2006; Rollnick et al. 2008). Despite its influence and success, however, the bulk of this research, although taking a first step in this direction, has arguably avoided many of the really difficult questions about the nature of 'universities themselves'. Focusing largely upon the cognitive processes of individual students, one of the main concerns of this research has been to find out what is wrong with students who do not engage in the ways that their tutors wish them to (Haggis 2003). In response to the repeated finding that large numbers of students appear not to be taking a deep approach, the question implied by the research seems to be "why do so many

*Email: tamsin.haggis@stir.ac.uk 
students take a surface approach to learning?' Despite nearly 40 years of concentrated research activity, this question appears to remain still largely unanswered.

In order to try to find out something about the nature of the research base in this area, a review of article titles relating to student learning was carried out in three key higher education journals. The article will first report on the results of this review, and then discuss these results in the context of theoretical moves in psychology and sociology over the same period of time. The trends identified in the higher education journals will then be compared to research into student learning in higher education which is published in two other disciplinary areas: adult education and sociolinguistics. After raising some questions that arise from these comparisons, the final section of the article will outline some tentative thoughts about my own attempts to work out ways of conceptualising and researching 'differently'.

\section{What do we know?}

In order to explore the question of 'what we know', a survey of article titles reporting on research into student learning was carried out in three key non-North American higher education journals, covering the period from the 1970s to the present day. The journals reviewed were Higher Education, Studies in Higher Education and Teaching in Higher Education. In terms of location and status, Tight (2007) has suggested that the journal Higher Education $(H E)$ is generally regarded as 'the leading non-North American international' higher education journal, and that Studies in Higher Education (SiHE) is 'the leading UK-based' journal $(2007,239)$. Teaching in Higher Education (THE), a more recent journal that has only been published since the late 1990s, was reviewed here in order to compare a newer, initially less prestigious, journal with the two more established ones. Although UK-based, these journals publish articles from a range of international authors, and are widely used in British, European, Australian, South African and Hong Kong higher education contexts (an extended version of this review, including comparisons with two key North American journals, is reported in Haggis 2009).

The focus of this analysis is on 'how learning is conceptualised in UK-based journal article titles'. In other words, what models/research do these articles appear to draw on, in terms of the language used in their titles? The purpose of the paper is to examine ideas about learning in higher education from the perspective of discussions about learning which take place in other, non-higher education contexts. These contexts include schools, further education, work-based learning, and professional learning. Conceptualisations of learning in many of these contexts have been influenced by 'big ideas' from psychology and sociology, which often extend beyond the UK (to, for example, North America and Russia). For this reason the discussion of theoretical moves in psychology and sociology is not restricted to the UK.

\section{Methodology}

In each journal, for each decade, a content analysis was performed on the language used in article titles relating to student learning. In order to do this, a working definition of 'student learning' had to be developed. This was problematic, as the distinction between learning and teaching begins to break down when examined closely, and of course the focus on titles only restricted the information available on each article. For the 'curricular innovation' category (discussed below) a decision was made to restrict the analysis to titles which explicitly mentioned learning in relation to new forms of 
curricula. Similarly, in the 'social context/student experience' category, titles referred to sociologically-based descriptions of students or student experience, rather than to organisational policies concerned with issues such as 'widening access'. The rationale for these decisions can be seen more clearly in relation to the questions connected to each category: what is being examined here is the way that learning is conceptualised (so, a widening access policy that aims to increase 'student support' may appear to be looking at learning as an institution-wide issue, but the conceptualisation of learning is still based on the idea of individual support).

The six categories generated in relation to the titles were 'cognitive psychology', 'approaches to learning', 'curricular innovation', 'social context/student experience', 'critical perspectives' and 'discourse/writing'. The categories were not restricted to areas such as 'theory' or 'methodology', but used a wider range of concepts in an attempt to capture the different areas of focus represented by the titles. Some of these could be classified as relating to specific theoretical approaches (e.g. 'cognitive psychology', 'approaches to learning', 'discourse analysis'), but others, such as 'curricular innovation' and 'social context/student experience' were not, or only partially so. Three passes through the total data set were performed in order to crossreference and confirm the categories.

That it was not possible to group the articles into solely theoretical areas is interesting. Though many of the perspectives categorised as 'social context', for example, are clearly broadly sociological, 'the student experience' aspect of this category can also incorporate a range of political agendas, as well as methodological approaches linked to quite specific (e.g. critical and emancipatory) strands of sociology. The category 'curricular innovation' represents a broad-based area of activity that might draw on any number of different theories, or possibly even have very little theoretical basis. For example, ideas such as 'peer-learning', 'problem-based learning' and 'self-regulated learning' could be seen to have developed as much in relation to cultural trends and value-positions as to research or theory. The discourse/writing category often reflects theoretical discourse analysis approaches, but also includes discussion of essay writing and writing skills.

Each category could be said to be attempting to answer a particular question. For example, cognitive psychology and approaches to learning might be said to be asking: 'What can we discover about how individuals learn?' Key words in cognitive psychology include: personality, ability, motivation, learning style/strategy, personal meaning, orientation, achievement, preference, study orchestration, and learning outcome. Approaches to learning includes phrases such as: approaches to study/learning, student perceptions/conceptions, deep learning, student ways of thinking, deep and surface. Although initially seeing itself as distinct from cognitive psychology, approaches to learning work arises within the cognitive tradition, and, as time goes on, titles indicated a blurring of the distinction between them; for example, in 1996, 'metacognitive, cognitive and affective aspects of learning styles and strategies: a phenomenographic analysis'; or, in 2002, 'validation of a free response test of deep learning about the normal swallowing process'.

Curricular innovation might be said to be asking the question: 'What are the implications of our knowledge about individual learning for classroom teaching and curriculum design?' (which approaches to learning researchers arguably extend to become 'How can we get students to take a deep approach to learning [the content of our curricula]?'). Key phrases in this category include: peer learning, collaborative learning, problem-based learning, learning for self-direction, task-based learning, negotiated learning, and resource-based learning. Article titles that were focused on 
teaching, instruction, or teacher action were not included in the analysis. Although this category appears to focus on 'teaching methods', titles here were only included if they focused on creating new kinds of learning experience.

Social context/student experience perspectives initially ask: 'What is going on outside the classroom which might impact upon learning outcomes?', and 'What do students themselves have to say about learning?' Later this focus extends to 'How does what is done in the classroom impact upon work and life prospects?', and finally to issues such as 'How can classroom experience serve the agenda of lifelong learning?' Key phrases here are: mature students, disability, students and social class, cultural/ social capital, gender/inequality, international students, the student experience, and recognising difference. Article titles which referred to participation statistics or organisational aspects of access policies were not included.

Critical perspectives ask questions such as: 'What are the limitations of our current positions and views about learning?' These perspectives were often indicated by a question mark, in combination with words such as critical/critique, challenge, hidden curriculum, transformation, power, tensions, transgression, and ethics.

Discourse and writing perspectives are an extension of both social/student experience and critical perspectives. These perspectives might ask questions such as 'What is the effect of particular types of language use in relation to student learning outcomes?', or 'How does the way we speak, and what we ask students to write, create impediments to students' learning?' Key words here included: writing skills training, writing experiences, academic literacies, writing styles and gender/achievement, dialogic behaviour, and participating in academic discourse.

The categories are listed above in the order that they appear in higher education journals through time. For example, there are no titles deemed to belong to the discourse/writing category in the 1970s; and social context and critical perspective titles become more prevalent throughout the decades.

\section{Articles on learning: 1970-2007}

Figure 1 summarises the relative proportions of the different categories in each journal for each decade.
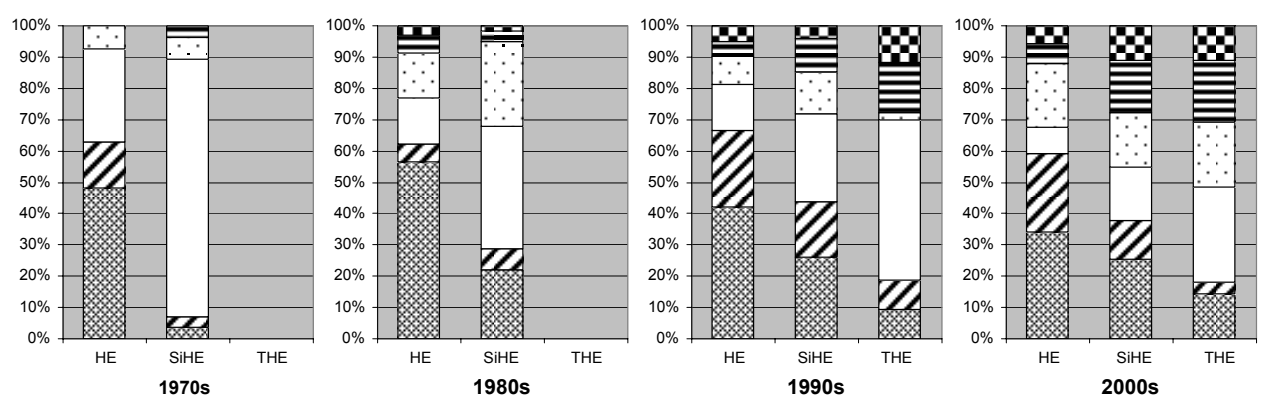

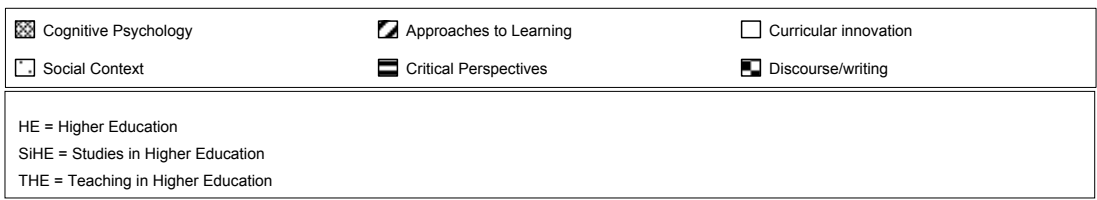

Figure 1. Content comparison through the decades. 
In the 1970s, the main focus of $H E$ in relation to learning appears to be the building of a knowledge base about individual student learning (cognitive psychology), and the development of a particular extension of this approach (approaches to learning). A smaller proportion of articles explore the application of this knowledge to practice (curricular innovation), and only a very small proportion of articles indicate an interest in understanding the effect of what goes on beyond the classroom (social context/ student experience). $\mathrm{SiHE}$, by contrast, appears relatively unconcerned with building or discussing the knowledge base, but is very interested in considering the implications of research ideas about learning to practical teaching.

In the 1980s, the interest in learning research and theory has increased in SiHE, whilst in $H E$ it remains proportionally the same. Learning research in $H E$, however, has slightly less of a focus in this decade upon approaches to learning perspectives. Social and critical perspectives are increasing, particularly in SiHE, with the combined effect of these increases resulting in a reduction in experimental approaches to teaching and the curriculum. Titles suggest that interest in learning is still overwhelmingly focused at the level of the classroom.

In the 1990s, HE's interest in building up a knowledge base about individual learning has increased very slightly, but is proportionally largely unchanged since the 1970s. Approaches to learning research, however, now makes up a much larger proportion of this focus. In the 1990s $H E$ is only marginally more interested in asking 'What's going on outside the classroom which might impact upon learning outcomes?' (social context/student experience) than it was in the 1970s, and is less interested in this question now than it was in the 1980s. It is also apparently slightly less interested in critiquing its perspectives than it was in the previous decade, though discourse/writing perspectives have increased. SiHE, though more prepared to engage in critique, also appears to be less interested in asking what is going on for students beyond the classroom than it was in the 1980s. Both journals show an increase in cognitive/approaches to learning articles, and a corresponding reduction in curricular innovation and social perspectives. THE, a new journal in this decade, goes against these apparent trends, returning to the much earlier interest in curricular innovation, and also developing critical perspectives to a greater degree.

By 2007, the three journals appear to have settled into a pattern in terms of distribution of focus. $H E$ continues to publish the largest amount of psychologically-based research and theory; THE publishes the least, and SiHE occupies a point between the two. Approaches to learning perspectives are reducing in both $\mathrm{SiHE}$ and THE, but not in $H E$. All three journals are less interested in discussing classroom practice than in addressing social and critical perspectives.

\section{Four decades of higher education research in its wider theoretical and disciplinary context}

The trends outlined in the higher education journals will now be compared with a brief summary of key theoretical moves in psychology and (to a lesser extent) sociology (see Table 1).

\section{$1970 \mathrm{~s}$}

In the 1970s, the higher education journals being reviewed here arguably take an individualistic approach to the study of student learning, which is rooted in both 
Table 1. Comparison of broad theoretical shifts in psychology, sociology, and higher education research through four decades.

\begin{tabular}{|c|c|c|c|}
\hline $1970 s$ & $1980 s$ & $1990 s$ & $2000 s$ \\
\hline $\begin{array}{l}\text { PSYCHOLOGY (individual/ } \\
\text { interactional): behaviourism/ } \\
\text { objectives (Bloom); cognitivism, } \\
\text { including interactional } \\
\text { perspectives (Dewey, Bruner, } \\
\text { Bandura, Leont'ev) and } \\
\text { developmental theories (Piaget, } \\
\text { Kohlberg, Erikson.); humanism } \\
\text { (Rogers, Maslow); } \\
\text { psychoanlaysis (Freud, Fromm, } \\
\text { Lacan) } \\
\text { SOCIOLOGY/SOCIAL THEORY } \\
\text { (social): neo-Marxism; } \\
\text { interactionism/interpretivism; } \\
\text { sociology of knowledge, } \\
\text { postmodern critique }\end{array}$ & $\begin{array}{l}\text { PSYCHOLOGY (individual/interactional/ } \\
\text { social): all previous perspectives plus } \\
\text { cognitive constructivism; social } \\
\text { constructivism; multiple and triarchic } \\
\text { theories of intelligence; socio-cultural } \\
\text { approaches (e.g. activity theory); community } \\
\text { psychology (radical social justice perspective } \\
\text { e.g. Burman); discourse perspectives; neural } \\
\text { networks, connectionism } \\
\text { SOCIOLOGY/SOCIAL THEORY (social): } \\
\text { agency, meaning, interaction, structure } \\
\text { (Goffman, Giddens); class, capital, power } \\
\text { (Habermas, Bourdieu); minority standpoint } \\
\text { epistemologies: gender, race, sexuality \& } \\
\text { disability; postmodern/post-structuralist } \\
\text { critique (Foucault, Lyotard) }\end{array}$ & $\begin{array}{l}\text { PSYCHOLOGY (individual/interactional/social/ } \\
\text { distributed/evolutionary): all previous plus } \\
\text { development of collaborative, cooperative and } \\
\text { discursive approaches; perspectives from } \\
\text { neuroscience (cognitive neuropsychology); } \\
\text { ecological and dynamic systems theories } \\
\text { (Maturana \& Varela; Fogel; Bosma \& } \\
\text { Kunnan); sociogenetics (Valsiner); } \\
\text { evolutionary perspectives } \\
\text { SOCIOLOGY/SOCIAL THEORY interactional/ } \\
\text { social/distributed/evolutionary/individual: all } \\
\text { previous perspectives continue and are joined } \\
\text { by, complexity theory and actor network } \\
\text { theory (Latour, Byrne, Law \& Urry); } \\
\text { morphogenetic theory (Archer) }\end{array}$ & $\begin{array}{l}\text { Continuing development of social/ } \\
\text { interactional, distributed, networked, } \\
\text { and emergentist perspectives in both } \\
\text { psychology and social theory. } \\
\text { Increasing amounts of interdisciplinary } \\
\text { work, and perspectives which try to } \\
\text { overcome the perceived boundaries } \\
\text { between social/biological/technological. }\end{array}$ \\
\hline \multicolumn{4}{|l|}{ HIGHER EDUCATION } \\
\hline $\begin{array}{l}\text { Individual: personality, attainment, } \\
\text { motivation, information- } \\
\text { retrieval, student type, } \\
\text { approaches to study, } \\
\text { perceptions, student learning } \\
\text { processes } \\
\text { Social: access, mature students }\end{array}$ & $\begin{array}{l}\text { Individual: affect, anxiety, self-directed } \\
\text { learning readiness scale, locus of control, } \\
\text { skills, conceptions, approaches, perceptions, } \\
\text { individualised learning, problem-based } \\
\text { learning, independent study } \\
\text { Social: access, comparative achievements of } \\
\text { conventional/ non-traditional students, } \\
\text { student experience, gender, mature students, } \\
\text { social class, social disadvantage, group work }\end{array}$ & $\begin{array}{l}\text { Individual: study orchestrations, learning } \\
\text { outcomes, study deficiencies, gender \& } \\
\text { learning style, learning behaviour, learning } \\
\text { strategies, approaches \& mature students/ } \\
\text { gender, perceptions, conceptions, self-directed } \\
\text { learning, problem-based learning, reflection } \\
\text { Social: mature students, class, gender, social } \\
\text { inequality, adult learning, student experience, } \\
\text { international students, disability }\end{array}$ & $\begin{array}{l}\text { Individual: individual differences/styles, } \\
\text { motivation, text \& learner variables, } \\
\text { learning outcomes, student type, } \\
\text { threshold concepts, attrition, } \\
\text { metacognition, dissonance, achievement, } \\
\text { approaches, perceptions, conceptions, } \\
\text { orientations, alienation/belonging, } \\
\text { active learning, self-directed learning, } \\
\text { experiential learning, learning journals. } \\
\text { Social: } \text { mature students, academic \& social } \\
\text { integration, diversity, student debt, } \\
\text { disabled students, adults, networked } \\
\text { learning, web-mediated discussion } \\
\text { (socio-culturally appropriate } \\
\text { methodologies, university culture, work- } \\
\text { related learning, power distance, } \\
\text { complexity, uncertainty) }\end{array}$ \\
\hline
\end{tabular}


behaviourist and cognitive psychology. Within this overall orientation, there is some quite radical thinking, demonstrated by titles such as 'a course without a structure', and 'freedom in the selection of course content'. The focus, however, is still predominately upon answering the questions 'What can we discover about how individuals learn?' and 'What are the implications of our knowledge about individual learning for classroom teaching and curriculum design?'

In this decade, the discipline of psychology is developing a much wider range of cognitive perspectives. Potentially relevant, among many others, are the social and interactional perspectives of Bandura and Leont'ev, and the philosophical perspective of John Dewey. In addition, humanistic psychologists such as Maslow and Rogers, and psychoanalytic theorists such as Erikson and Freud, are developing ideas which are being rapidly taken up by those who teach adults in contexts other than universities (see the section on adult education).

\section{$1980 \mathrm{~s}$}

In the 1980 s the higher education journals continue to take a predominately individualistic approach to the study of student learning, demonstrated most clearly by the overall increase in cognitive and approaches to learning perspectives. The potentially radical questioning of the $1970 \mathrm{~s}$ in relation to curricular innovation appears to become reined in during the $1980 \mathrm{~s}$, particularly in $H E$, with discussions of self-managed and structure-free learning giving way to discussion of more manageable technologies such as peer teaching and problem-based learning. In this decade social context perspectives also begin to increase, but these are arguably limited to attempts to answer the question, 'What's going on outside the classroom which might impact upon learning outcomes?' The focus of titles in this category is largely limited to a concern for the effects of access movements, and the resulting influx into higher education of 'non-standard' entrants, though a small number of articles reflect an interest in the 'minority standpoint epistemologies' of gender, race, sexuality and disability which are developing at this time in sociology (Ball 2004).

In the 1980s in psychology itself, cognitive and constructivist approaches are developing into a range of social and interactional perspectives, which explore the relationship between individual and 'context' in a variety of much more complicated and nuanced ways. Social constructivist approaches in general, and particular sociocultural approaches such as activity theory, begin to consider the implications of not thinking of the individual as at the centre of all that might be designated 'learning'. This is a radical conceptual departure which is still almost completely absent in the non-North American higher education journals by 2007. In addition, the 1980s sees the development of more politically radical branches of psychology, such as community psychology, which critique and challenge mainstream psychology from a sociological perspective. In sociology, major theoretical work in relation to the relationship between the individual and society is being carried out by theorists such as Giddens, Habermas and Bourdieu, and a range of critical perspectives are being developed from feminist and postmodern positions.

\section{$1990 s$}

The relative absence of this more nuanced and critical approach to the theorisation of individual and society continues, although to differing degrees, in the higher education 
journals throughout the 1990s. Apparently largely uninterested in developments in psychology and sociology, $H E$ in particular maintains its focus on the more individualistic and static aspects of cognitive psychology, and in this decade significantly increases its coverage of approaches to learning research. Although the other two journals are slightly more interested in critical and/or social perspectives, these are largely confined to critiquing new teaching methodologies and/or discussing generalised (and often psychologised) notions of gender, class and the student experience.

Whilst higher education is focusing in this decade largely upon developing the concerns it identified in the 1980s (with very little critique of such concerns), the fields of psychology and sociology are witnessing the emergence of more new theoretical developments. Resulting partly from increasingly cross-disciplinary flows of critique and ideas, these developments arguably have the potential to reframe the very foundations of the social sciences, and to liberate research thinking in hitherto unimaginable directions. In developmental psychology, for example, ideas from ecological and dynamic systems theories begin to create a range of fluid, dynamic and de-centred notions of self and society. In sociology, actor network theory creates new possibilities for a simultaneous framing of the social, biological and technological in networked relations through time, while complexity theory offers a radically contingent and dynamic perspective from which to consider the emergence of adaptive specificity and difference across a range of disciplines.

\section{$2000 s$}

As these new perspectives are continuing to develop throughout the 2000s, the higher education journals apparently show little awareness of their existence. There is not yet even much discussion of theorists such as Habermas and Bourdieu (recent books by researchers such as Mclean [2006] and Archer, Hutchings, and Ross [2003] do explore these perspectives, but they are rarely represented in the three journals being examined here), and, in $H E$ and $S i H E$, there is a very limited amount of self-referential critique. $T H E$ is the journal most influenced by critical perspectives in sociology, but it too shows little sign of any interest in the ecological, dynamic systems and network theorisations occurring in other fields. In all of the journals there is some discussion of networks in relation to web-based and online learning, but this review of titles, at least, gives no indication of any of the radical questioning of conventional epistemologies and ontologies which is being explored in other disciplines.

Compared to other disciplines over this period, then, when it comes to discussions about learning (and with some notable exceptions; see, for example, Webb 1997; Terenzini, 1999; Mann 2001) it can be seen that the higher education journals, and $H E$ in particular, focus on a very narrow range of possible perspectives and methodologies. These are not only narrow in the sense that they are restricted to a predominately psychological approach to learning (Malcolm and Zukas 2001), but also narrow in terms of the field of psychology itself. Even in the 2000s, a great deal of discussion about learning in higher education is still focused upon the same basic questions that arose in the 1970s; 'What can we discover about how individuals learn?', 'What are the implications of our knowledge about individual learning for classroom teaching and curriculum design?', 'How can we get students to take a deep approach to learning the content of our curricula?', and 'What is going on outside the classroom which might impact upon learning outcomes?' THE is the only journal which explores questions such as 'What is the effect of particular types of language use in relation to student 
learning outcomes?', or 'How does the way we speak, and what we ask students to write, create impediments to students' learning?' in any detail. Thus, $H E$, and to a lesser extent also $\mathrm{SiHE}$ (the two most prestigious journals), are usually at least one, and sometimes two, decades behind research in the two fields which have traditionally most directly informed the development of educational theory.

This lack, or, in the case of SiHE and THE, relatively late, engagement with critical and social perspectives in the mainstream higher education journals does not, however, mean that no critical or social research has been carried out in the context of higher education. Relevant and challenging work has been carried out in two other disciplinary areas: adult education and sociolinguistics. Researchers in these fields do occasionally publish in higher education journals (see, for example, Lillis and Turner 2001; Boud and Lee 2005), but in the main this work has been published in the specialist journals of each field.

\section{Adult Education}

A comparison of the review of higher education journals carried out above with the leading UK-based journal in the field of adult education, Studies in the Education of Adults (SEA), for the 2000s, shows that $S E A$ is dominated by the perspectives that are very limited in the two high-status higher education journals (see Figure 2). Though UK-based, SEA represents perspectives of North American, European, South African and Australasian researchers, as well as writers from the UK.

Adult education has been much more influenced throughout the decades by the changes and shifts in the wider intellectual worlds of the social sciences and the humanities. For example, in the 1970s and 1980s, when humanistic psychology is developing in psychology, adult learning theory begins to experiment with a wide range of ideas from humanism (e.g. self-actualisation, facilitation, self-direction, experience, reflection). The reflexive critique which can be seen in the 1970s in fields such as sociology begins to affect adult education by the 1980s, as researchers such as Brookfield (1993) and Boud (1990) bring critical reflexivity to bear, not only on new teaching ideas and methodologies, but also on the field of adult education itself. By
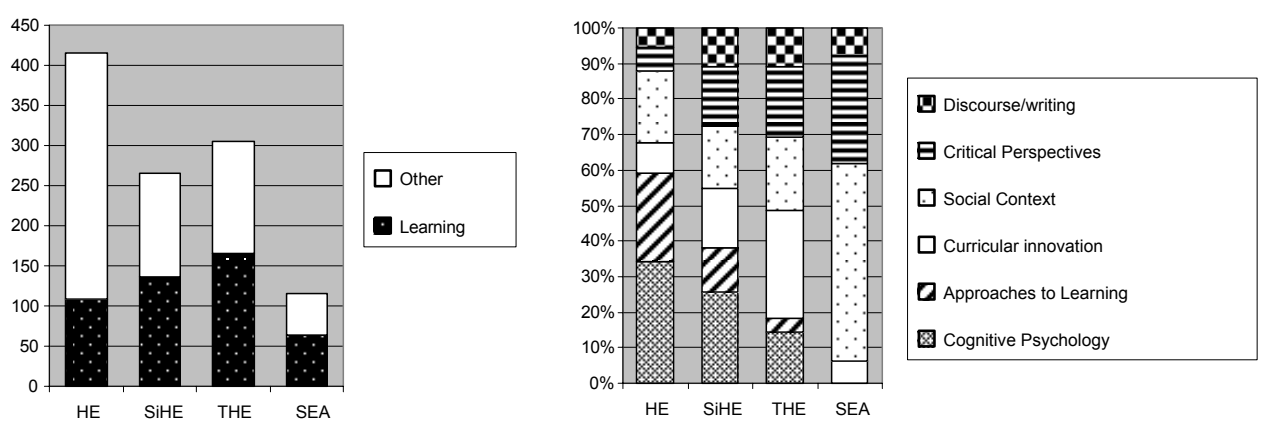

$$
\begin{aligned}
& \mathrm{HE}=\text { Higher Education } \\
& \text { SiHE = Studies in Higher Education } \\
& \text { THE = Teaching in Higher Education } \\
& \text { SAE = Studies in the Education of Adults }
\end{aligned}
$$

Figure 2. Comparative balance of article focus in three leading higher education journals and the leading adult education journal (2000s). 
the 1990s, when the two main higher education journals are only just beginning to develop critical perspectives, adult education is critiquing every one of its central concepts, including the 'adult' in adult education, and the policy contexts (such as 'lifelong learning') within which its activities are embedded. At this time, adult education is also engaging with a range of issues related to learning for and in work, and drawing upon a range of socio-cultural and postmodern/post-structural theories.

By the 2000s, adult educators have been critiquing their own field from Marxist/ neo-Marxist, postmodern/post-structural and feminist perspectives for a number of decades.

In contrast to higher education's ongoing attempt to establish a robust, 'evidencebased' theory of individual learning, in adult education the influence of postmodernism/ post-structuralism and critical theory is by now raising questions about the nature of knowledge, and considering the implications of seeing knowledge itself as de-centred, contingent, distributed, and social. A comparison of article titles focused on learning in the most recent volumes of SiHE and $S E A$ available online at the time of writing gives an indication of the differing content of these two journals today (see Table 2).

\section{Sociolinguistics}

The discourse/genre work arising out of the second area, sociolinguistics, is grounded in new literacy studies (Thesen and Van Pletzen 2006), exemplified by the work of Barton, Gee, Ivanič, and Street (see Barton, Hamilton, and Ivanič 2000). Arguing for a view of literacy practices as social, context-specific, patterned by power relations, historically situated, and dynamic (Barton, Hamilton, and Ivanič 2000, 8), this work brings together the socio-cultural concerns of contemporary approaches in the social sciences and post-structural/discourse approaches in the humanities. The research from this perspective which focuses specifically on higher education has become known as 'academic literacies'.

Academic literacies research first starts to make an appearance in the higher education context in the late 1990s, with the publication of an article by Lea and Street in SiHE (1998), and the books Student writing in higher education (Lea and Stierer) in 2000, and Student writing (Lillis) in 2001. As far as can be seen from the review of titles, $H E$ publishes no research related to this tradition, with the exception of a very interesting article by Francis and Hallam in 2000, and Mann's equally interesting paper on the student experience of reading (also 2000). SiHE publishes a very small number of articles in the following years; notably Francis, Robson, and Read in 2001, and Robson, Francis, and Read, and Lea in 2004. THE, on the other hand, publishes a range of articles taking an academic literacies approach, focusing on issues such as critical approaches to text, and the analysis of communication and discourse.

Despite its extraordinary relevance for developing a wider range of understandings of teaching and learning, and, even more importantly, as a source of potentially generative/transformative critique of higher education cultures and practices, most academic literacies research is not published in the higher education journals being examined here. Whilst some academic literacies researchers are on the editorial boards or review for SiHE and THE, most of their work is not published in these journals, with the result that staff in higher education who might benefit from this work are very likely not aware that it exists. They will probably never see, for example, the special issue of the Journal of Applied Linguistics which came out in 2007, 
Table 2. Comparative titles of articles on learning in recent volumes of SiHE and SEA (the two most current volumes available online in August 2007).

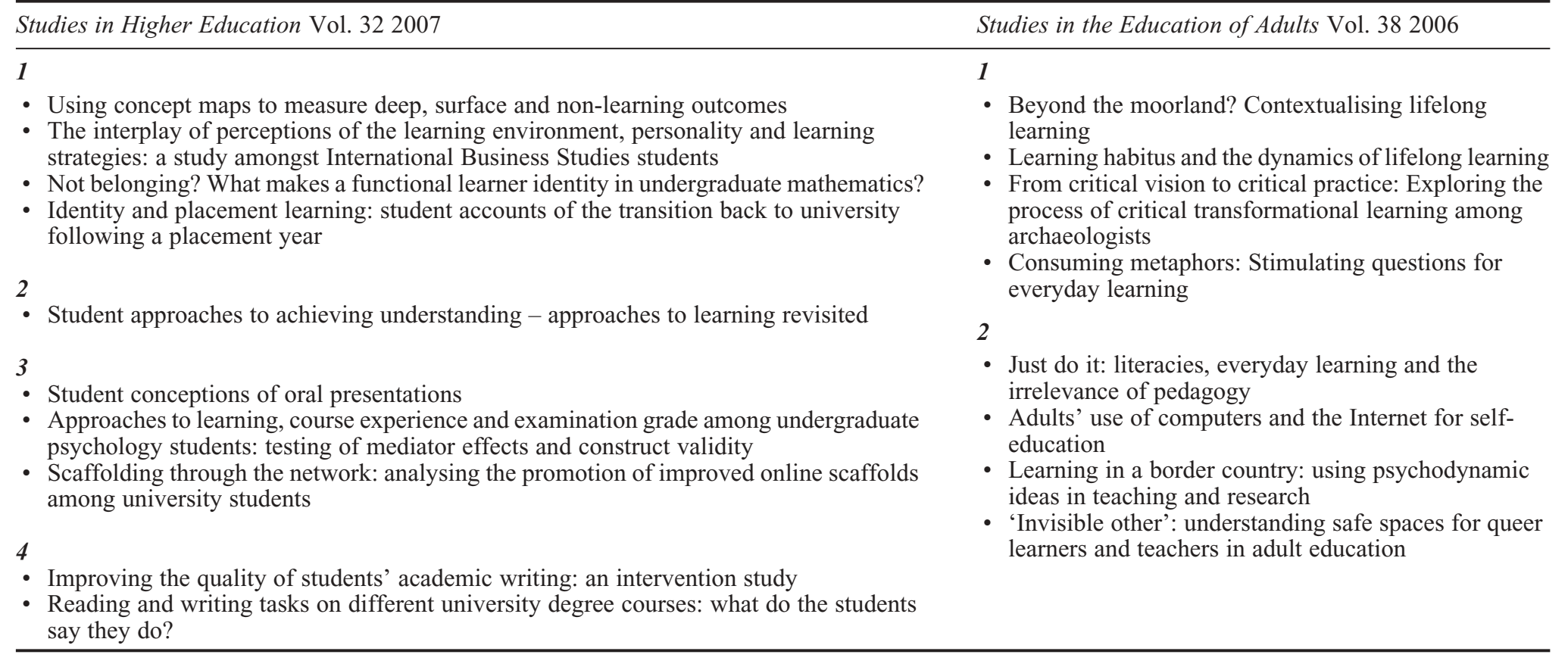

- Beyond the moorland? Contextualising lifelong learning

Learning habitus and the process of critical transformational learning among Conseologists

- Consuming metaphors: Stimulating questions for 2 education

Learning in a border country: using psychodynamic teaching and research

Reading and writing tasks on different university degree courses: what do the students hey do? 
or the recent work in South Africa collected together in Thesen and Van Pletzen (2006).

In concluding this review, then, it can be said that what we know about student learning depends on where we look, and is always a reflection of specific purposes and interests, which are tied to particularities of temporal and spatial contexts. One characteristic of the theoretical shifts which I argue have been largely ignored is an increasing demand for critical reflexivity; a call to pay attention not only to issues such as gender and power, but to turn this attention back on all of the practices and assumptions of teachers and researchers themselves. The field of higher education has arguably focused most of its efforts until very recently upon attempting to shore up certainties in relation to knowledge of students as 'other', and has not been particularly good at examining its own cultures and ways of being. In the wider world of education, 'what we know' is contradictory and contested, and is understood to be rooted inextricably in value positions. It is only recently in higher education, however, that a range of different perspectives have begun to emerge, and finding ways to really engage with value positions is still arguably problematic.

\section{What do we need to know?}

The issues discussed in this review lead to a number of questions which could be explored further. The first issue is what the focus of the two high-status journals through the years reveals about the cultures and practices of (non-North American) higher education to date. As well as considering what is valuable about these cultural biases, there is arguably also a need to consider how we are ourselves contributing (both as researchers and as practitioners) to aspects of these biases which may not always be productive, in ways that we find hard to see. We need to continue to look for ways to better understand the value-laden nature, and effects, of our own positions. The adult education and sociolinguistics literatures can be very helpful here, as there is already a considerable body of research in each of these disciplines which is directly relevant to the issues and questions raised in this discussion. In adult education, for example, there is a long history of debate about many of the teaching methodologies and ideas which are either still relatively new to higher education, or which often exist in higher education contexts in rather simplistic and reduced forms. These include self-directed learning, experiential learning, learning contracts, profiling, and ideas such as 'learner responsibility' and 'autonomy' which underpin such methodologies. The literatures of adult and professional education also contain decades of discussion and debate about the nature of workplace learning and learning for work, again directly relevant to the increasingly work-focused agenda being imposed on higher education.

If we can begin to stand even further outside the results of our own enculturation and start to see things differently, a further question is how it might be possible to find productive and generative ways of challenging aspects of what we see that we wish to change. This challenge is extremely difficult in the current context of massification, increased pressure to produce economically-relevant student outcomes, underfunding, and other factors which are often interpreted as being a threat to academic identity. A particular challenge in relation to the theory and research of learning is the consideration of what it would mean to shift from an individual to a social approach to understanding learning in higher education. 


\section{What we might do about it}

In response to this review of titles relating to student learning in a selection of UKbased higher education journals, I have argued that we need to do everything we can to get out of our own comfortable, cultural milieu. We need to find ways of standing outside of our histories, circumstances and fields, and of examining our epistemological and ontological assumptions. I have argued that we need to know not only more but differently, and to keep on extending the range of our different ways of knowing. It has been suggested that existing research in the fields of adult education and sociolinguistics offer relevant and well-theorised work specific to higher education, which could act as a productive starting point for doing this. Beyond this, recent developments in psychology and social science (e.g. community psychology, dynamic systems theory, actor network theory and complexity theory, to name but a few) offer the potential for developing radically new perspectives, if we can be brave enough to try to engage with them.

In more general terms, there are many aspects of learning that are still not well understood, which currently dominant ontologies and epistemologies struggle to investigate and represent. For example, research into learning is still not able to deal well with 'the fleeting', 'the distributed', 'the multiple' and 'the complex' (Law and Urry 2003, 10). To my knowledge, there is as yet little research that attempts to document different types of dynamic interaction and process through time in relation to 'learning' situations in higher education. For example, there are few ethnographies (see Nespor [1994] for an important exception), although academic literacies research has begun one strand of work from this perspective. The attempt to work with and across a variety of disciplines is fraught with difficulties and challenges, involving identity risks and the creation of endless and unforeseen vulnerabilities. But if we are serious about trying to do justice to our students in terms of understanding what we currently deem to be 'their' learning, we too need to step into the unknown.

\section{Note}

The journal review discussed in this article has also been published as: T. Haggis (2009) Student learning research: A broader view, in The Routledge international handbook of higher education, ed. M. Tight, K.H. Mok, J. Huisman, and C. Morphew, chap. 4. New York: Routledge.

\section{References}

Archer, L., M. Hutchings, and A. Ross. 2003. Higher education and social class. London: RoutledgeFalmer.

Ball, S., ed. 2004. The RoutledgeFalmer reader in sociology of education. London: Routledge. Barton, D., M. Hamilton, and R. Ivanič. 2000. Situated literacies: Reading and writing in context. London: Routledge.

Boud, D. 1990. Assessment and the promotion of academic values. Studies in Higher Education 15, no.1: 101-11.

Boud, D., and A. Lee. 2005. 'Peer learning' as pedagogic discourse for research education. Studies in Higher Education 30, no. 5: 501-16.

Brookfield, S. 1993. Self-directed learning, political clarity and the critical practice of adult education. Adult Education Quarterly 43, no. 4: 227-42.

Francis, B., J. Robson, and B. Read. 2001. An analysis of undergraduate writing styles in the context of gender and achievement. Studies in Higher Education 26, no. 3: 313-26.

Francis, H., and S. Hallam. 2000. Genre effects on higher education students' text reading for understanding. Higher Education 39, no. 3: 279-96. 
Gorsky, P., A. Caspi, and R. Trumper. 2006. Campus-based university students' use of dialogue. Studies in Higher Education 31, no. 1: 71-87.

Haggis, T. 2003. Constructing images of ourselves? A critical investigation into 'approaches to learning' research in higher education. British Educational Research Journal 29, no. 1: 89-104.

Haggis, T. 2009. Student learning research: A broader view. In The Routledge international handbook of higher education, ed. M. Tight, K.H. Mok, J. Huisman, and C. Morphew, chap. 4. New York: Routledge.

Law, J., and J. Urry. 2003. Enacting the social. http://www.comp.lancs.ac.uk/sociology/ papers/Law-Urry-Enacting-the-Social.pdf.

Lea, M. 2004. Academic literacies: A pedagogy for course design. Studies in Higher Education 29, no. 6: 739-56.

Lea, M., and B. Stierer. 2000. Student writing in higher education. Buckingham: Open University Press.

Lea, M., and B. Street. 1998. Student writing in higher education: An academic literacies approach. Studies in Higher Education 23, no. 2: 157-72.

Lillis, T. 2001. Student writing: Access, regulation and desire. London: Routledge.

Lillis, T., and J. Turner. 2001. Student writing in higher education: Contemporary confusion, traditional concerns. Teaching in Higher Education 6, no. 1: 57-68.

Malcolm, J., and M. Zukas. 2001. Bridging pedagogic gaps: Conceptual discontinuities in higher education. Teaching in Higher Education 6, no. 1: 33-42.

Mann, S. 2000. The students' experience of reading. Higher Education 39, no. 3: 297-317.

Mann, S. 2001. Alternative perspectives on the student experience: Alienation and engagement. Studies in Higher Education 26, no. 1: 7-19.

Marton, F., and R. Säljö, R. 1984/1997. Approaches to learning. In The experience of learning, ed. F. Marton, D. Hounsell, and N. Entwistle, 1st and 2nd eds. Edinburgh: Scottish Academic Press.

Maton, K. 2004. The field of higher education. PhD thesis, University of Cambridge.

McLean, M. 2006. Pedagogy and the university: Critical theory and practice. London: Continuum.

Nespor, J. 1994. Knowledge in motion: Space, time and curriculum in undergraduate physics and management. London: Falmer Press.

Robson, J., B. Francis, and B. Read. 2004. Gender, student confidence and communicative styles at university: The views of lecturers in history and psychology. Studies in Higher Education 29, no. 1: 7-23.

Rollnick, M., B. Davidowitz, M. Keane, A. Bapoo, and L. Magadla. 2008. Students' learningapproach profiles in relation to their university experience and success. Teaching in Higher Education 13, no. 1: 29-42.

Terenzini, P. 1999. Research and practice in undergraduate education: And never the twain shall meet? Higher Education 38, no. 1: 33-48.

Thesen, L., and E. van Pletzen. 2006. Academic literacy and the languages of change. London: Continuum.

Tight, M. 2007. Bridging the divide: A comparative analysis of articles in higher education journals published inside and outside North America. Higher Education 53, no. 2: 235-53.

Webb, G. 1997. Deconstructing deep and surface: Towards a critique of phenomenography, Higher Education 33, no. 2: 195-212. 